\title{
Oncogenic osteomalacia: loss of hypophosphatemia might be the key to avoid misdiagnosis
}

\author{
Osteomalacia oncogênica: a perda de fosfatemia pode \\ ser a chave para evitar o diagnóstico incorreto
}

Claudia V. Chang', Sandro J. Conde', Renata A. M. Luvizotto', Vânia S. Nunes', Milla C. Bonates', Andre C. Felicio², Susan C. Lindsey', Flávia H. Moraes', José V. Tagliarini', Glaucia M. F. S. Mazeto', Peter Kopp³', Célia R. Nogueira'

1 Department of Medicine, Faculdade de Medicina de Botucatu, Universidade Estadual de São Paulo (Unesp), Botucatu, SP, Brazil ${ }^{2}$ Department of Neurology and Neurosurgery, Universidade Federal de São Paulo (Unifesp), São Paulo, SP, Brazil

${ }^{3}$ Division of Endocrinology, Metabolism and Molecular Medicine Northwestern University, Chicago, United States

Correspondence to: Claudia V. Chang Rua Itapeva, 202, cj. 129 01332-000 - São Paulo, SP, Brazil chang.cv@gmail.com

Received on May/28/2012 Accepted on Oct/26/2012

\section{SUMMARY}

Diagnosing oncogenic osteomalacia is still a challenge. The disorder is characterized by osteomalacia caused by renal phosphate wasting and low serum concentration of 1,25-dihydroxyvitamin $D_{3}$ occurring in the presence of a tumor that produces high levels of fibroblast growth factor 23. However, it is possible that the disease is much more misdiagnosed than rare. We present the case of a 42-year-old man with a long-term history of undiagnosed progressive muscle weakness. His laboratory results mainly showed low serum phosphate. Surgical removal of a nasal hemangiopericytoma that had been diagnosed five years earlier, brought him to a symptom-free condition. Even though knowing the underlying etiology would explain his osteomalacia, the patient sought medical help from countless physicians for five consecutive years, and only after adequate treatment a rewarding outcome was achieved. Arq Bras Endocrinol Metab. 2012;56(8):570-3

\section{SUMÁRIO}

A osteomalacia oncogênica é um diagnóstico clínico desafiador, caracterizado pela perda renal de fosfato e baixos níveis de 1,25-di-hidroxivitamina $D_{3^{\prime}}$ ocorrendo na presença de um tumor produtor de altos níveis de fator de crescimento de fibroblasto 23. No entanto, é possível que se trate muito mais de uma falha de diagnóstico clínico do que propriamente uma doença rara. Os autores relatam o caso de um homem de 42 anos com histórico de fraqueza muscular progressiva por cinco anos e restrição à cadeira de rodas, sem diagnóstico. Seus exames laboratoriais evidenciavam baixos níveis de fósforo. A remoção cirúrgica de um hemangiopericitoma detectado previamente em cavidade nasal levou à resolução completa dos sintomas. Os autores enfatizam que, mesmo com a etiologia já evidenciada, o paciente consultou diversos clínicos no decorrer dos cinco anos até que fossem instituídos o diagnóstico e o tratamento adequados. Arq Bras Endocrinol Metab. 2012;56(8):570-3

\section{INTRODUCTION}

$\mathrm{O}$ ncogenic osteomalacia is a rare but potentially life-threatening condition most often misdiagnosed and mistreated in clinical practice. The exact mechanisms implicated in the pathogenesis of oncogenic osteomalacia remain elusive. Recently, the identification of fibroblast growth factor-23 (FGF23) in oncogenic osteomalacia tumors led to new insights into the understanding of this phosphate-wasting disorder. It seems that FGF23, a phosphatonin that is overexpressed by tumor cells, is responsible for the lack of phosphate reabsorption in the proximal tubule of the kidney, along with an inappropriately low level of 1,25-dihydroxyvi$\operatorname{tamin} \mathrm{D}_{3}(1,2)$.

Here, we report a case of confirmed tumorinduced oncogenic osteomalacia with mRNA FGF23 overexpression, highlighting the difficulty in diagnosing this disorder. 


\section{CASE REPORT}

At the age of 37 , this Brazilian-white man was admitted to our Otorhinolaryngological Unit due to episodic events of epistaxis and nasal obstruction. Clinical evaluation revealed a mass in the nasal cavity, which was biopsied and the histological analysis revealed that the tumor corresponded to a nasal hemangioperycitoma. Unfortunately, the patient missed follow-ups for five consecutive years and did not return to check the results. Hence, other laboratory tests, such as the measurement of serum phosphorus, were not requested. Meanwhile, he visited countless physicians complaining basically of general muscle weakness and pain, which gradually worsened, leading to progressive walking difficulty. Several treatment attempts to relief his symptoms repeatedly failed.

Five years later, the patient was re-admitted at the Emergency Room reporting progressive disability. He was a wheelchair-user, and was diagnosed with femur fragility fracture. There was progressive height loss, and significant bone deformity (Figure 1). At that moment (second hospitalization) a bone biopsy was carried out, showing mature bone tissue with irregular areas of osteoid and immature bone. He had no symptoms of malabsorption, and no family history of metabolic bone disease.

Physical examination revealed that his blood pressure was $120 / 85 \mathrm{mmHg}$, and pulse was regular at 78 beats per minute. Neurological examination showed reduction of reflexes. Muscle strength was graded IV $/ \mathrm{V}$ on all four limbs.

His laboratory tests showed calcium of $2.3 \mathrm{mmol} / \mathrm{L}$ (RV:2.1-2.6 mmol/L), creatinine level of $0.7 \mathrm{mg} /$ $\mathrm{dL}(61.88 \mu \mathrm{mol} / \mathrm{L})$, low serum phosphorus of $0.5 \mathrm{l}$ mmol $\backslash \mathrm{L}$ (RV:0.81-1.45 mmol/L), PTH:53.3 pg/ml (11-65 pg/mL), inappropriately normal phosphaturia of $851.64 \mathrm{mg} / 24 \mathrm{~h}(400-1,300 \mathrm{mg} / 24 \mathrm{~h})$, and low tu-

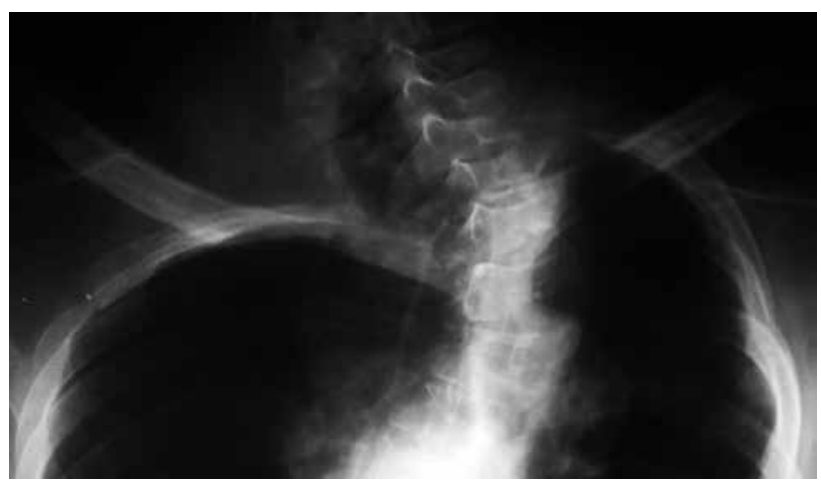

Figure 1. Scoliosis, convex to the left, in the thoracic region. Radiolucent areas at the end of the clavicles. bular reabsorption of phosphate at $72 \%$ (normal range $78-98 \%$ ), thus indicating renal phosphate wasting. His 25-hydroxyvitamin $\mathrm{D}$ was normal, but 1,25-dihydroxyvitamin $\mathrm{D}_{3}$ level was also inappropriately normal (26 pg/mL; RV:9-52 pg/mL).

As the biopsy performed 5 years earlier showed a nasal hemangioperycitoma, and taking into consideration the clinical complaint of progressive muscle weakness and pain, the radiological evidence of osteomalacia, together with hyphophosphatemia and low tubular reabsorption of phosphate, the hypothesis of underlying oncogenic osteomalacia was considered.

A new evaluation of the previously detected nasal cavity mass using computer tomography and magnetic resonance imaging confirmed the presence of the tumoral mass. An expanding lesion occupied almost the whole left (L) nasal cavity with solid ethmoidal cells on the left with heterogeneous intravenous contrast. Eroded bone walls from the L maxillary sinus, ethmoid and sphenoid bone, and L lamina papyracea were observed. The mass measured 7X4X6 cm and extended to the interior of the rhinopharynx. Since we did not have access to either fgf 23 serum level data, or information about other factors related to tumor-induced osteomalacia, we opted to use a molecular biology tool in this case. The tumor was completely removed at that moment, and total RNA of the tumoral mass was extracted using Trizol reagent (Invitrogen). One microgram of total RNA was reverse-transcribed with SuperScript III First-Strand Synthesis System for Reverse Transcription (RT) PCR (Invitrogen, Cat. no.: 18080-051).

Quantitative real-time PCR was used to study FGF23 mRNA expression. The real-time RT-PCR was carried out using the SYBR Green I chemistry method (SYBR Green Quantitect RT-PCR Kit, Applied Biosystems). An ABI Prism 7700 system (PerkinElmer Life sciences, Boston, MA, USA) was employed to quantitatively measure FGF23, and cyclophilin (internal control) mRNA expression. All assays were performed in duplicate. The mRNA contents were normalized to the cyclophilin mRNA levels, and differences in expression were determined by the Ct method described in the ABI user's manual (Applied Biosystems). This assay showed overexpression of FGF23 mRNA in the tumor tissue compared to normal tissue (Figure 2).

After complete resection of the nasal hemangiopericytoma, the patient became symptom-free, laboratory parameters were normalized, and he noticed progressive improvement of his muscle strength. 


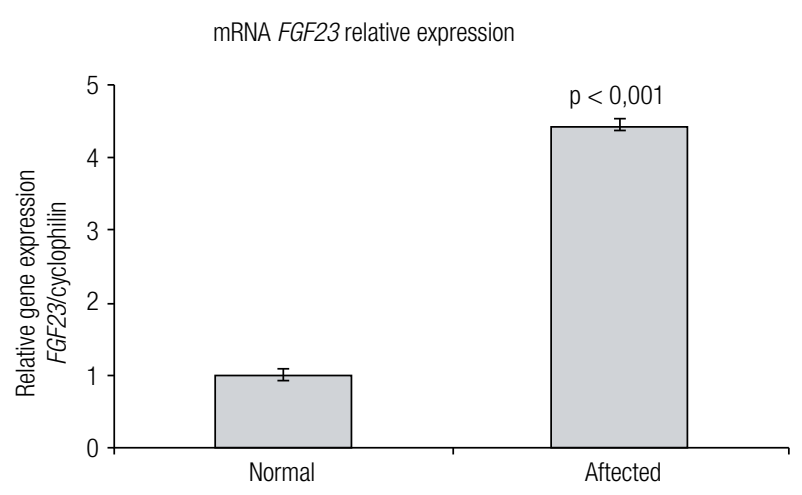

Figure 2. Relative FGF23 expression for normal (nasal tissue) and affected tissues (hemangyopericitoma). The mRNA expression was quantified by qPCR, and cyclophilin was used to normalize FGF23 expression. Differences in expression were determined by the Ct method (2 $\left.2^{\Delta \Delta C}\right)$ (Student's t test; $p<0.05)$.

\section{DISCUSSION}

There are several case reports in clinical medicine considered as rare diseases, but the patient presented here might be much more a case of misdiagnosis than of another rare disease. Even though the patient had a previously known underlying etiology that could have explained his osteomalacia, he sought medical help from countless physicians for five consecutive years, and only after adequate treatment a rewarding outcome was achieved.

There is a range of metabolic bone disorders that lead to osteomalacia. They include inborn metabolism errors (autosomal dominant hypophosphatemic rickets, and X-linked hypophosphatemic rickets), malabsorption, and chronic renal disease (3). Oncogenic osteomalacia is considered a very rare cause of osteomalacia. This case report reinforces that oncogenic osteomalacia should be taken into consideration in patients with long-term complaints of muscle weakness or bone pain/fractures. The biochemical assessment reveals low serum phosphate in patients afflicted by oncogenic osteomalacia. Moreover, treating physicians should be aware of the paraneoplastic nature of this disorder, and should eagerly seek to locate the tumor site because tumor-resection may completely restore the functional capacity of the patient.

Most commonly, mesenchymal tumors are responsible for oncogenic osteomalacia. They are generally placed in the lower (45\%) or upper (17\%) extremities, and less often in the cranio-cervical region (4). It is usually very difficult to locate the tumor site, and work- up requires numerous imaging procedures and modalities (5). Even with modern techniques of molecular imaging, it is not easy to both locate and identify these tumors. Fortunately, in the case presented here, the tumor had been previously identified, a fact that greatly facilitated us to establish the diagnosis of the mass, and the management of our patient.

Soft tissue and bone tumors of various types (hemangiopericytomas, hemangiomas, giant cell tumors, osteoblastomas) have been associated with oncogenic osteomalacia. Among these tumors, hemangiopericytomas are probably the most common neoplasms, but the incidence and prevalence rates are still unknown (3). Hemangiopericytomas usually present as slow-growing, painless masses. The diagnosis of hemangiopericytoma is mainly based on the presence of a special histologic architecture, formed by small cells of uniform shape that are tightly packed, and surrounding vascular channels with very thin walls (6).

FGF23 was originally identified as responsible for the autosomal dominant hypophosphatemic rickets (1), but it is also involved in the pathogenesis of oncogenic osteomalacia (2). Previous studies have shown that elevated FGF23 concentrations found in preoperative sera of patients with oncogenic osteomalacia normalize after resection of the causative tumor. Additionally, specific study of FGF23 (serum level, immunostaining or mRNA expression in the neoplastic tissue) of the causative tumor might be useful clinical markers for the diagnosis and management of patients with oncogenic osteomalacia (7).

Once the tumor is located, the treatment of choice is complete resection. Failure to normalize the associated oncogenic osteomalacia may be due to the presence of residual tumor, or an additional occult causative lesion.

In conclusion, physicians should have heightened awareness in patients with long-term complaints of muscle weakness and pain/bone fractures, and should include oncogenic osteomalacia in their list of differential diagnosis. The documentation of low serum phosphorus levels and high phosphatonin enables a quite easy diagnosis of this condition. The measurement of serum FGF23 levels may further support the diagnosis of this tricky, and often inefficiently-handled, phosphate-wasting disorder.

Disclosure: no potential conflict of interest relevant to this article was reported. 


\section{REFERENCES}

1. White KE, Jonsson KB, Carn G, Hampson G, Spector TD, Mannstadt $\mathrm{M}$, et al. The autosomal dominant hypophosphatemic rickets $(A D H R)$ gene is a secreted polypeptide overexpressed by tumors that cause phosphate wasting. J Clin Endocrinol Metab. 2001;86(2):497-500.

2. White $K E$, Larsson TE, Econs MJ. The roles of specific genes implicated as circulating factors involved in normal and disordered phosphate homeostasis: frizzled related protein-4, matrix extracellular phosphoglycoprotein, and fibroblast growth factor 23 . Endocr Rev. 2006;27(3):221-41.

3. Folpe $A L$, Fanburg-Smith JC, Billings SD, Bisceglia M, Bertoni $F$, Cho JY, et al. Most osteomalacia-associated mesenchymal tumors are a single histopathologic entity: an analysis of 32 cases and a comprehensive review of the literature. Am J Surg Pathol. 2004;28(1):1-30.

4. Ryan EA, Reiss E. Oncogenous osteomalacia. Review of the world literature of 42 cases and report of two new cases. Am J Med. 1984;77(3):501-12

5. Chong WH, Yavuz S, Patel S, Chen CC, Collins MT. The importance of whole body imaging in tumor-induced osteomalacia. J Clin Endocrinol Metab. 2011;96(12):3599-600.

6. Fuentealba C, Pinto D, Ballesteros F, Pacheco D, Boettiger O, Soto N et al. Oncogenic hypophosphatemic osteomalacia associated with a nasal hemangiopericytoma. J Clin Rheumatol. 2003;9(6):373-9.

7. Nelson AE, Bligh RC, Mirams M, Gill A, Au A, Clarkson A, et al. Clinical case seminar: fibroblast growth factor 23: a new clinical marker for oncogenic osteomalacia. J Clin Endocrinol Metab. 2003;88(9):4088-94. 